\title{
Holy Grail: the journey towards disease modification in asthma
}

\author{
William W. Busse ${ }^{1}$, Erik Melén $\mathbb{1}^{2}$ and Andrew N. Menzies-Gow ${ }^{3}$
}

${ }^{1}$ Dept of Medicine, Division of Allergy, Pulmonary and Critical Care Medicine, University of Wisconsin School of Medicine and Public Health, Madison, WI, USA. ${ }^{2}$ Dept of Clinical Science and Education Södersjukhuset, Karolinska Institutet and Sachs' Children's Hospital, Stockholm, Sweden. ${ }^{3}$ Dept of Respiratory Medicine, Royal Brompton Hospital, London, UK.

Correspondence: William W. Busse (wwb@medicine.wisc.edu)

Shareable abstract (@ERSpublications)

Asthma is a complex, heterogeneous disease, which currently has no cure; this review explores the disease-modifying potential of asthma therapies and the direction future research may take to achieve disease remission or prevention. https://bit.ly/31AxYou

Cite this article as: Busse WW, Melén E, Menzies-Gow AN. Holy Grail: the journey towards disease modification in asthma. Eur Respir Rev 2022; 31: 210183 [DOI: 10.1183/16000617.0183-2021].

Copyright (C)The authors 2022

This version is distributed under the terms of the Creative Commons Attribution Non-Commercial Licence 4.0. For commercial reproduction rights and permissions contact permissions@ersnet.org

Received: 30 July 2021 Accepted: 28 Nov 2021

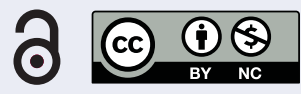

\section{Abstract}

At present, there is no cure for asthma, and treatment typically involves therapies that prevent or reduce asthma symptoms, without modifying the underlying disease. A "disease-modifying" treatment can be classed as able to address the pathogenesis of a disease, preventing progression or leading to a long-term reduction in symptoms. Such therapies have been investigated and approved in other indications, e.g. rheumatoid arthritis and immunoglobulin E-mediated allergic disease. Asthma's heterogeneous nature has made the discovery of similar therapies in asthma more difficult, although novel therapies (e.g. biologics) may have the potential to exhibit disease-modifying properties. To investigate the disease-modifying potential of a treatment, study design considerations can be made, including: appropriate end-point selection, length of trial, age of study population (key differences between adults/children in physiology, pathology and drug metabolism) and comorbidities in the patient population. Potential future focus areas for disease-modifying treatments in asthma include early assessments (e.g. to detect patterns of remodelling) and interventions for patients genetically susceptible to asthma, interventions to prevent virally induced asthma and therapies to promote a healthy microbiome. This review explores the pathophysiology of asthma, the disease-modifying potential of current asthma therapies and the direction future research may take to achieve full disease remission or prevention.

\section{Introduction}

Asthma is a chronic inflammatory respiratory condition, affecting over 350 million people worldwide [1]. Although most asthma deaths are preventable, nearly 400000 people died from asthma in 2015 [1]. At present, there is no cure and current treatments are typically classified as "controllers" (e.g. inhaled corticosteroids (ICS)) or "relievers" (e.g. short-acting beta-agonists), meaning they prevent or reduce asthma symptoms without modifying the underlying disease [2].

To go further than the prevention/reduction of asthma symptoms and potentially achieve asthma remission, a disruption of the critical pathobiological mechanisms of the disease (and the timing of such) is likely to be important [2]. Although there is a lack of consensus on the definition of a disease-modifying therapy, the goal is to prevent disease progression or achieve remission [3]. When considering whether disease modification has been achieved, it is important to distinguish temporary therapeutic benefits from those that affect the course of the disease over time [4]. It is also important to consider whether the therapy under investigation could be prescribed in addition to existing treatments or could replace them, thus reducing the patient's medication burden. This is particularly important for exacerbation-prone patients with more severe disease, who are likely to be on a greater number of controller therapies [5].

Although there are currently no approved disease-modifying therapies for asthma, disease remissions have been successful with the treatment of other diseases [6]. For example, disease-modifying anti-rheumatic drugs (DMARDs) are immunosuppressive and immunomodulatory agents, falling under the classifications 
of either biologic or conventional DMARDs [7]. Conventional synthetic DMARDs (e.g. methotrexate) and biologic DMARDs (e.g. adalimumab) act on the immune system to slow the progression of rheumatoid arthritis (RA) [8, 9]. Through the use of DMARDs, some RA patients stay symptom-free even after treatment has stopped [10].

Another disease-modifying therapy is allergen immunotherapy (AIT), including oral immunotherapy (OIT), as a treatment for immunoglobulin E (IgE)-mediated allergic disease [11, 12]. The therapy involves treatment with increasing doses of a sensitising allergen, which has the capacity to reduce responsiveness to the allergen [12]. When this effect persists, it is considered as tolerance. AIT has been implemented for the treatment of allergic rhinitis (AR), allergic asthma, allergic rhinoconjunctivitis and stinging insect venom allergy [11]. This method is thought to be disease modifying, as effects last beyond treatment cessation [11]. Furthermore, patients with AR have a higher chance of developing asthma than those without, meaning that successfully treating AR with AIT may reduce the risk of developing asthma [11, 13]. In patients with food allergy, OIT has emerged as a novel disease-modifying treatment option [12]. However, despite appearing to be a promising modality for food allergy treatment, it is unknown at this stage whether OIT is likely to induce permanent allergen tolerance [12].

Novel therapies for asthma, such as biologics, may have the potential to promote disease modification. This narrative review will explore the pathophysiology of asthma, summarise the current literature on the disease-modifying potential of current asthma therapies and describe the direction we feel future research may take to achieve full disease remission or prevention.

\section{Asthma pathophysiology}

The pathophysiology of asthma involves a complex interplay between airway inflammation and airway remodelling, which typically results in airway hyperresponsiveness (AHR), defined as variable and excessive airway narrowing [14]. Asthma progression is indicated by an accelerated loss of lung function over time [15, 16], and is partially driven by exacerbations [17]. Patients with asthma can be broadly split into two phenotypes, based on their levels of type 2 inflammation: type 2 (T2) and non-T2 asthma [18] (figure 1 [19-22]). T2 asthma is driven by T2 inflammation, typically characterised by high levels of eosinophils, fractional exhaled nitric oxide $\left(F_{\mathrm{ENO}}\right)$, total serum IgE, and T2 inflammatory cytokines such as interleukin (IL)-4, IL-5 and IL-13. More recently, the role of the innate immune system via innate lymphoid cells type 2 (ILC2) has been recognised. In the absence of T2-mediated allergy, eosinophilic

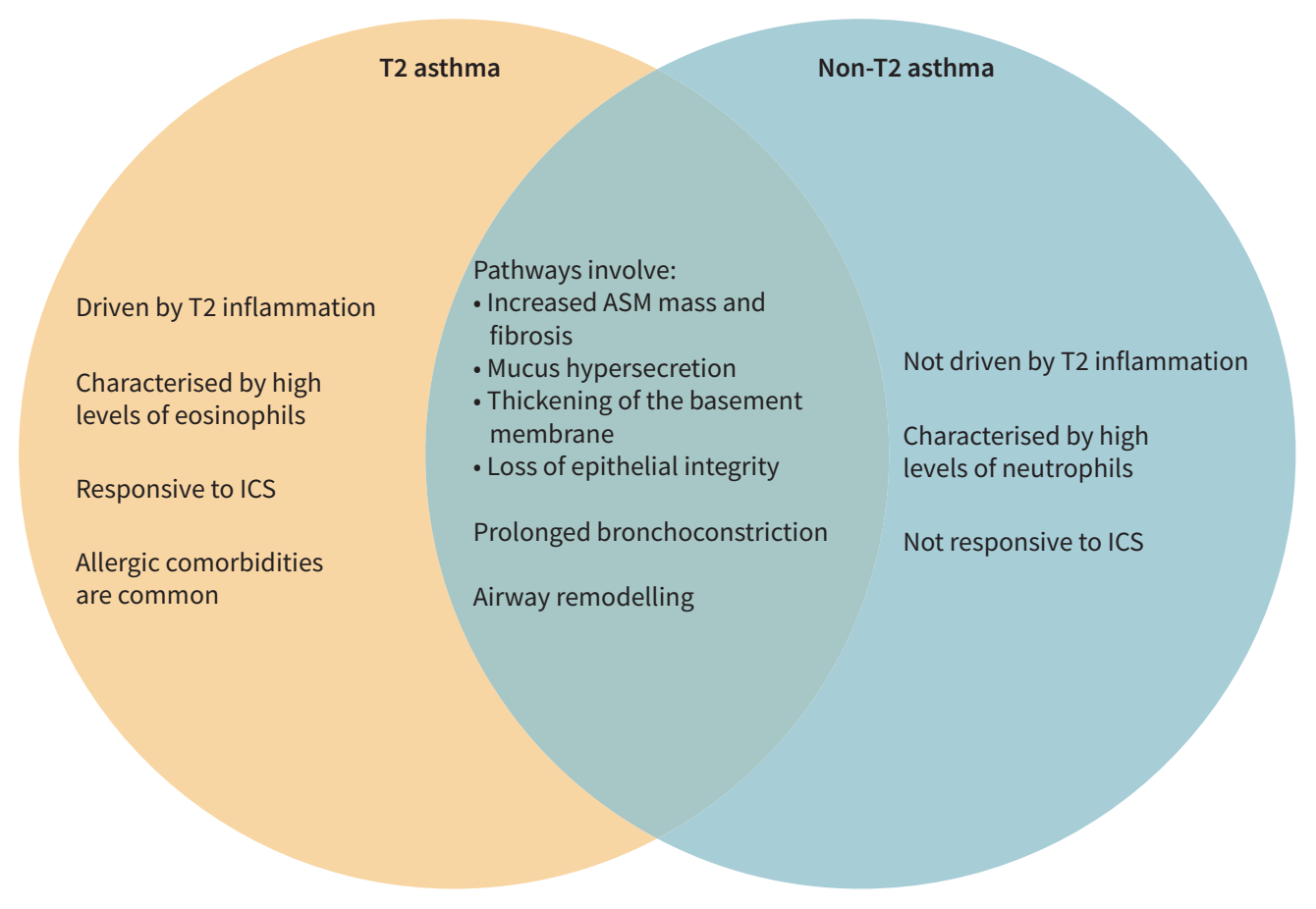

FIGURE 1 Similarities and differences in type 2 (T2) and non-T2 asthma [19-22]. ASM: airway smooth muscle; ICS: inhaled corticosteroid; T2: type 2. 
inflammation is thought to be a result of increased ILC2, which produce T2-associated cytokines upon stimulation with epithelial-derived cytokines (including high amounts of IL-5, which is important for eosinophil maturation and migration) [23, 24]. Elevated eosinophils are associated with more severe asthma, including increased exacerbation rates, AHR and airway obstruction; eosinophil count can also be an overall predictor of severe exacerbations [22, 25, 26]. Compared with T2 asthma, the pathophysiology of non-T2 asthma is less well understood; however, it has been linked to the activation of T-helper (Th)1 and/or Th17 cells and an imbalance of Th17/T-regulatory cells [22, 27] triggered by infections and/or inhaled pollutants [28]. It is thought that up to $50 \%$ of adults with asthma may present with non-T2 asthma [29]. However, there is evidence that high-dose ICS and oral corticosteroids may downregulate T2 biomarkers, making it difficult to determine the true prevalence of non-T2 disease [30, 31].

Both T2 and non-T2 asthma can result in airway remodelling (figure 1), with the extent of remodelling usually increasing over time and with disease severity [20, 21]. Elevated eosinophils contribute greatly to airway remodelling and AHR by causing persistent inflammation and damage to the airways [20]. Cytokines IL-4, IL-5 and IL-13, produced by activated Th2 and ILC2 cells, contribute by promoting eosinophil recruitment, leading to AHR and airway remodelling [14]. IgE is also involved in the pathogenesis of airway remodelling and plays a central role in the causality of asthma-related symptoms [32]. Allergic asthma often has an early onset of symptoms [33], and more than $50 \%$ of children and adolescents with asthma are sensitised to common allergens [34-36].

\section{Defining disease modification}

To investigate the potential disease-modifying properties of an asthma therapy, it is key to understand the definitions of disease modification and/or remission in the context of asthma. A disease-modifying treatment can be described as one that treats the pathogenic mechanisms of disease to prevent disease progression, or a sustained reduction in symptoms and disease activity beyond the temporary effects of other interventions. It is important for such declines in clinical signs/symptoms to be accompanied by significant effects on validated biomarkers and measures that reflect key pathophysiological aspects of the underlying disease pathophysiology [4]. As disease severity may naturally vary over a patient's lifetime (e.g. children with asthma may outgrow their symptoms) [3], it is important that patient history and predisposition to disease be considered by clinicians.

In a recent Delphi study, disease remission was defined in the context of asthma: participants stated that any definition of asthma remission should address current symptom burden, recent exacerbation incidence, future exacerbation risk, absence of ongoing airway inflammation and the prevention of accelerated lung function decline and airway remodelling [3]. The study outcome was a framework comprising definitions for clinical remission and complete remission either on- or off-treatment (figure 2; further information on definitions of remission can be found in Menzies-Gow et al. [3]).

\section{Asthma therapies: evidence of disease modification}

\section{ICS}

The evidence of ICS effect on disease modification is varied. Evidence to date from large clinical trials does not support a strong disease-modifying effect of ICS in preventing the development of persistent asthma in children [37-40]. In adults with asthma, ICS has been demonstrated to decrease airway wall area and thickness [41-43], and vascular area [42, 44] in small-scale studies; however, data reported are variable and controversial, especially when considering the technical aspects of the measures used [45]. Data on rates of remission whilst on ICS are very sparse. Although controller medications such as ICS are often effective at producing disease control whilst on treatment, thus meeting some definitions for disease remission, many patients remain uncontrolled despite high-dose or long-term treatment [46, 47], particularly those with severe disease. One 12-year study found that despite cumulative increases in ICS over time, cases of remission in patients with adult-onset asthma were very low [47], suggesting that ICS may not be sufficient to manage adult-onset disease or produce a disease-modifying effect in this patient group.

\section{Bronchial thermoplasty}

Bronchial thermoplasty is a device-based therapy comprising the controlled delivery of thermal energy to the airways to target excess airway smooth muscle (ASM) and possibly affect its function [48]. Though it has been shown to reduce ASM mass and reticular basement membrane thickness in patients with severe asthma [48, 49], suggesting it may have an effect on airway remodelling, it is an invasive procedure and has been used in a limited number of patients, making it unlikely to replace long-term ICS. However, it has provided prolonged disease control in some patients with severe asthma [50]. Its mechanisms of action remain unknown, the phenotype of asthma most responsive has not been defined, and the positioning of bronchial thermoplasty use has not been fully established [22, 51, 52]. 


\section{Clinical remission on treatment}

For $\geq 12$ months:
- Sustained absence of significant asthma symptoms
based on validated instrument, and
- Optimisation and stabilisation of lung function, and
- Patient and HCP agreement regarding disease
remission, and
- No use of systemic corticosteroid therapy for
exacerbation treatment or long-term disease control
Complete remission on treatment
Clinical remission plus the following:
- Current, objective evidence of the resolution
of previously documented asthma-related inflammation
(e.g. reduced blood or sputum eosinophil counts, $F_{\mathrm{ENO}}$
and/or other relevant measures), and
- In appropriate research settings: current negative
bronchial hyperresponsiveness

\section{Clinical remission off treatment}

Same criteria maintained without asthma

treatment for $\geq 12$ months

\section{Complete remission off treatment}

Same criteria maintained without asthma treatment for $\geq 12$ months

FIGURE 2 Generalised framework for remission in asthma criteria for clinical and complete remission, on and off treatment, were identified by consensus among clinical experts. HCP: healthcare provider. Blood eosinophil counts and fractional exhaled nitric oxide $\left(F_{\mathrm{ENO}}\right)$ are less relevant for non-type 2 asthma. Reproduced from [3] with permission.

\section{Biologics}

Biologic therapies target the inflammatory modulators identified as components in the pathways involved in asthma pathogenesis, predominantly in patients with T2 inflammation [53]. Some approved biologics have been shown to have the potential for disease modification (table 1 and figure 3 [54]).

\section{Anti-lgE}

IgE is an important mediator of allergic reactions, including allergic asthma. Omalizumab is an anti-IgE monoclonal antibody $(\mathrm{mAb})$ approved for patients aged $\geqslant 6$ years with severe allergic asthma with elevated IgE [55]. Omalizumab binds to and reduces free IgE, which is associated with a reduction in high-affinity IgE receptor expression in basophils, mast cells and dendritic cells [56, 57], in turn leading to decreased markers of inflammation associated with airway remodelling (e.g. IL-4, IL-5 and IL-13) [57]. As IgE receptors are also expressed on ASM cells [28], it is conceivable that anti-IgE therapies may have disease-modifying potential.

Some studies have demonstrated a reduction in exacerbations with omalizumab [58, 59], and limited studies have also shown an improvement in lung function [60, 61]. Evidence suggests that omalizumab remains effective after discontinuation (table 1) [62, 63], implying disease-modifying potential. Omalizumab has also been demonstrated to reduce airway wall thickness [64, 65], as well as to decrease the levels of proteins related to airway remodelling [65]. A recent study showed that in patients with aspirin-exacerbated respiratory disease, omalizumab led to a rapid reduction in median urinary leukotriene $\mathrm{E}_{4}$ and suppression of leukotrienes and other inflammatory mediators, likely due to the disarming of mast cells [66]. These findings indicate that a modified response to aspirin may have been achieved. Combined, these results suggest that omalizumab may have disease-modifying properties; however, larger studies with longer follow-up periods are required to fully investigate whether disease-modifying effects would be maintained. An ongoing phase II study (PARK; NCT02570984, estimated completion November 2025) is investigating whether 2 years of omalizumab treatment could prevent the development of childhood asthma when administered to 250 high-risk children aged 2-3 years [67]. Primary outcomes are active asthma diagnosis and asthma severity, assessed in the final 12 months during a 2-year observation period off the study drug. 


\section{TABLE 1 Treatments with published evidence to suggest disease-modifying potential in asthma}

\begin{tabular}{|c|c|c|c|}
\hline Drug name & Drug class & Therapeutic target & Key evidence to suggest disease-modifying potential \\
\hline \multirow[t]{3}{*}{$\begin{array}{l}\text { Fluticasone } \\
\text { propionate }\end{array}$} & ICS & NA & $\begin{array}{l}\text { WARD et al. [41] } \\
52 \text {-week randomised placebo-controlled trial in adults with asthma ( } n=35) \text {. } \\
750 \mu \mathrm{g} \text { twice daily decreased reticular basement membrane thickness. }\end{array}$ \\
\hline & & & $\begin{array}{l}\text { CHETTA et al. [42] } \\
6 \text {-week randomised parallel-group trial in adults with mild-to-moderate } \\
\text { asthma }(n=30) \text {. } \\
500 \mu \text { twice daily decreased reticular basement membrane thickness, number of } \\
\text { vessels and vascular area. }\end{array}$ \\
\hline & & & $\begin{array}{l}\text { HosHino et al. }[43] \\
16 \text {-week study in adults with steroid-naïve asthma and healthy controls ( } \mathrm{n}=62 \text { ). } \\
800 \mu \mathrm{gg} \cdot \mathrm{day}^{-1} \text { decreased airway wall area and thickness, as well as percentage of } \\
\text { eosinophils and serum periostin. }\end{array}$ \\
\hline $\begin{array}{l}\text { Beclomethasone } \\
\text { dipropionate }\end{array}$ & ICS & NA & $\begin{array}{l}\text { HosHino et al. [44] } \\
6 \text {-month randomised placebo-controlled trial in adults with asthma ( } \mathrm{n}=28) \text {. } \\
800 \mu \mathrm{g} \cdot \text { day }^{-1} \text { decreased vascular area and number of vessels. }\end{array}$ \\
\hline \multirow[t]{5}{*}{ Omalizumab } & Biologic & Anti-IgE & $\begin{array}{l}\text { Nopp et al. [62] } \\
\text { 3-year withdrawal follow-up study of omalizumab in adults with severe allergic } \\
\text { asthma ( } \mathrm{n}=18 \text { ). } \\
67 \% \text { patients reported improved or unchanged asthma } 3 \text { years after } \\
\text { discontinuation of omalizumab. }\end{array}$ \\
\hline & & & $\begin{array}{l}\text { MoLIMARD et al. [63] } \\
\text { Observational retrospective study in children and adults with severe allergic } \\
\text { asthma ( } n=61 \text { ). } \\
44 \% \text { reported no loss of asthma control after discontinuation of omalizumab } \\
\text { (median follow-up: } 9.3 \text { months). }\end{array}$ \\
\hline & & & $\begin{array}{l}\text { HosHINo and OHTAWA [64] } \\
\text { 16-week study in adults with severe allergic asthma }(n=30) \text {. } \\
\text { Add-on omalizumab treatment significantly reduced airway wall thickness versus } \\
\text { conventional therapy. }\end{array}$ \\
\hline & & & $\begin{array}{l}\text { Riccio et al. [65] } \\
\text { 3-year study in patients with severe allergic asthma }(n=8) \text {. } \\
\text { Omalizumab responders had a reduction in reticular basement membrane } \\
\text { thickness and decreased levels of proteins specifically related to } \\
\text { airway remodelling. }\end{array}$ \\
\hline & & & $\begin{array}{l}\text { HAYASHI et al. [66] } \\
\text { Randomised, crossover, placebo-controlled, single-centre study in adults with } \\
\text { aspirin-exacerbated respiratory disease }(n=16) \text {. } \\
\text { Omalizumab led to a rapid reduction in median urinary } \mathrm{LTE}_{4} \text { and suppression of } \\
\text { leukotrienes and other inflammatory mediators. Likely due to disarming of mast } \\
\text { cells and potentially indicative of a modified response to aspirin. }\end{array}$ \\
\hline \multirow[t]{3}{*}{ Dupilumab } & Biologic & Anti-IL-4R & $\begin{array}{l}\text { CASTRO et al. [70] } \\
\text { Phase III Liberty Asthma QUEST study in patients } \geqslant 12 \text { years with uncontrolled } \\
\text { asthma ( } n=1902 \text { ). } \\
\text { Dupilumab reduced serum IgE levels. }\end{array}$ \\
\hline & & & $\begin{array}{l}\text { CoRREN et al. [71] } \\
\text { Post hoc analysis of patients from Liberty Asthma QUEST study classified by } \\
\text { allergic status (allergic } n=1083 \text {, non-allergic } n=819 \text { ). } \\
\text { Dupilumab reduced serum IgE levels irrespective of allergic status. }\end{array}$ \\
\hline & & & $\begin{array}{l}\text { WECHSLER et al. [73] } \\
\text { Open-label, } 96 \text {-week extension study in patients } \geqslant 12 \text { years with } \\
\text { moderate-to-severe or OCS-dependent severe asthma from previous phase II or } \\
\text { III dupilumab trials ( } \mathrm{n}=2282 \text { ). } \\
\text { By week } 96 \text {, dupilumab reduced IgE levels by a median of } 82 \% \text { from parent study. }\end{array}$ \\
\hline Mepolizumab & Biologic & Anti-IL-5 & $\begin{array}{l}\text { FLOOD-PAGE et al. [78] } \\
\text { Study based on bronchial biopsies from adults with mild allergic asthma ( } \mathrm{n}=24) \text {. } \\
\text { After } 8 \text { weeks of treatment, mepolizumab administered intravenously reduced } \\
\text { airway mucosal eosinophils, and reduced expression of markers of airway } \\
\text { remodelling (ECM proteins tenascin, lumican and procollagen 3) compared } \\
\text { with placebo. }\end{array}$ \\
\hline
\end{tabular}




\section{TABLE 1 Continued}

\begin{tabular}{|c|c|c|c|}
\hline Drug name & Drug class & Therapeutic target & Key evidence to suggest disease-modifying potential \\
\hline Benralizumab & Biologic & Anti-IL-5 & $\begin{array}{l}\text { CHACHI et al. [83] } \\
\text { Computational model based on bronchial biopsies from adults with eosinophilic } \\
\text { asthma }(n=25) \text {. } \\
\text { Benralizumab significantly reduced ASM mass and number of eosinophils } \\
\text { versus placebo. }\end{array}$ \\
\hline \multirow[t]{2}{*}{ Tezepelumab } & Biologic & Anti-TSLP & $\begin{array}{l}\text { SRIDHAR et al. [89] } \\
\text { Phase IIb PATHWAY trial in adults with uncontrolled asthma ( } \mathrm{n}=550) \text { [156]. } \\
\text { Tezepelumab decreased serum levels of matrix remodelling proteins (MMP-10, } \\
\text { periostin), and blood eosinophil and } F_{\text {ENO }} \text { levels over } 52 \text { weeks. }\end{array}$ \\
\hline & & & $\begin{array}{l}\text { SVERRILD et al. [90] } \\
\text { Phase II UPSTREAM trial in adults with asthma and AHR to mannitol }(n=40) \text {. } \\
\text { Proportion of patients without AHR to mannitol after } 12 \text { weeks was significantly } \\
\text { greater in patients receiving tezepelumab }(p=0.04) \text {. } \\
12 \text { weeks of tezepelumab did not significantly reduce AHR to mannitol versus } \\
\text { placebo }(p=0.06) \text {. }\end{array}$ \\
\hline Montelukast & $\begin{array}{l}\text { Small-molecule } \\
\text { drug }\end{array}$ & CysLT antagonist & $\begin{array}{l}\text { DeBELLeIx et al. [99] } \\
\text { Pre-clinical study in immature and adult mouse models of AHR. } \\
\text { Montelukast decreased ASM mass in young developing mice, indicating the } \\
\text { potential to reverse (or even prevent) airway remodelling. }\end{array}$ \\
\hline \multirow[t]{2}{*}{ Fevipiprant } & $\begin{array}{l}\text { Small-molecule } \\
\text { drug }\end{array}$ & $\begin{array}{c}\mathrm{PGD}_{2} \text { receptor } 2 \\
\text { antagonist }\end{array}$ & $\begin{array}{l}\text { Gonem et al. [101] } \\
\text { Single-centre, randomised, placebo-controlled phase II trial in adults with } \\
\text { moderate-to-severe asthma ( } n=61 \text { ). } \\
\text { After } 12 \text { weeks, fevipiprant significantly increased the proportion of intact } \\
\text { epithelium and decreased functional residual capacity and expiratory CT } \\
\text { lung volume. }\end{array}$ \\
\hline & & & $\begin{array}{l}\text { SAUNDERS et al. [103] } \\
\text { Computational model to capture airway remodelling based on bronchial biopsies } \\
\text { from a phase II trial in adults with moderate-to-severe asthma [101]. } \\
12 \text { weeks of fevipiprant significantly decreased ASM mass versus placebo by } \\
\text { decreasing airway eosinophilia and recruitment of myofibroblasts and fibrocytes } \\
\text { to the ASM bundle. }\end{array}$ \\
\hline Roflumilast $^{\#}$ & $\begin{array}{l}\text { Small-molecule } \\
\text { drug }\end{array}$ & $\mathrm{PDE}_{4}$ inhibitor & $\begin{array}{l}\text { KIm et al. [105] } \\
\text { Pre-clinical study in a murine model of chronic asthma. } \\
\text { Roflumilast significantly decreased parameters of airway remodelling (goblet cell } \\
\text { hyperplasia and pulmonary fibrosis). }\end{array}$ \\
\hline Dasatinib & $\begin{array}{l}\text { Small-molecule } \\
\text { drug }\end{array}$ & TKI & $\begin{array}{l}\text { DA SILVA et al. [107] } \\
\text { Pre-clinical study in a murine model of allergic asthma. } \\
\text { Dasatinib attenuated alveolar collapse and contraction index and reduced } \\
\text { inflammatory cell influx to the airway, indicating that dasatinib could therefore } \\
\text { be used to reduce the remodelling process. }\end{array}$ \\
\hline
\end{tabular}

AHR: airway hyperresponsiveness; ASM: airway smooth muscle; COPD: chronic obstructive pulmonary disease; CT: computed tomography; CysLT: cysteinyl leukotriene; ECM: extracellular matrix; $F_{\mathrm{ENO}}$ : fractional exhaled nitric oxide; ICS: inhaled corticosteroid; IgE: immunoglobulin E; IL: interleukin; IL-4R: IL-4 receptor; $\mathrm{LTE}_{4}$ : leukotriene $\mathrm{E}_{4}$; MMP: matrix metalloproteinase; NA: not applicable; OCS: oral corticosteroid; $\mathrm{PDE}_{4}$ : phosphodiesterase-4 inhibitor; $\mathrm{PGD}_{2}$ : prostaglandin $\mathrm{D}_{2}$; TKI: tyrosine kinase inhibitor; TSLP: thymic stromal lymphopoietin. \#: non-asthma indication.

Anti-IL-4R

IL-4 and IL-13 play a key role in the pathophysiology of T2 asthma. Dupilumab is an mAb against the IL-4 receptor alpha (IL-4R $\alpha$ ) subunit of IL-4 and IL-4/IL-13 receptor complexes. It is approved as an add-on maintenance therapy for patients $\geqslant 12$ years with severe eosinophilic asthma [68]. Produced by activated T2 cells and promoting eosinophilia, IL-4 and IL-13 are major contributors to AHR and airway remodelling [14]. IL-13 facilitates ASM contraction and proliferation, goblet cell hyperplasia, AHR, increased extracellular matrix (ECM) secretion by fibroblasts and subepithelial basal membrane thickening; all of which are features of airway remodelling [69].

In phase II and III studies, dupilumab reduced serum IgE levels [70, 71], reduced severe exacerbation rates and improved lung function (table 1) [70-72]. An open-label extension study found that by week 96, dupilumab reduced IgE levels by a median of $82 \%$ from the parent study baseline [73]. As previously discussed, anti-IgE properties may be indicative of disease modification potential [74]. 


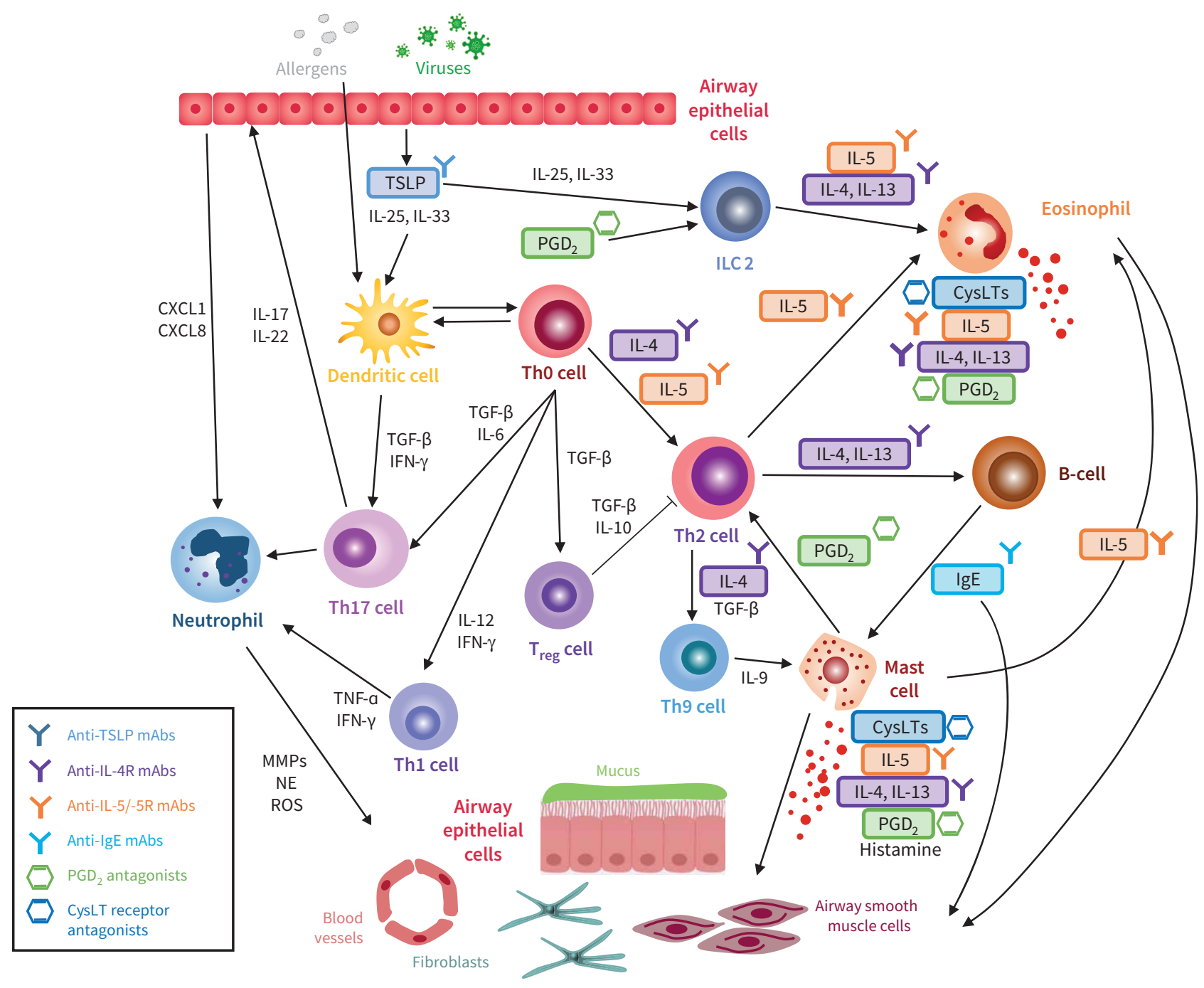

FIGURE 3 Asthma therapies that have exhibited disease-modifying potential and their therapeutic targets in the inflammatory cascade. CXCL: C-X-C motif chemokine ligand; CysLT: cysteinyl leukotriene; IFN- $\gamma$ : interferon gamma; IgE: immunoglobulin E; IL: interleukin; ILC 2: innate lymphoid cells type 2; mAb: monoclonal antibody; MMP: matrix metalloproteinase; NE: neutrophil elastase; $\mathrm{PGD}_{2}$ : prostaglandin $\mathrm{D}_{2}$; ROS: reactive oxidative stress; TGF- $\beta$ : transforming growth factor beta; TSLP: thymic stromal lymphopoietin; Th: T-helper cell; $T_{\text {reg: }}$ T-regulatory cell. Adapted from [54].

The ongoing VESTIGE study (NCT04400318; estimated completion October 2022) may provide an indication of whether dupilumab has further disease-modifying properties [75]. The primary end-point of this study was the effect of dupilumab on lung function and related changes in airway volumes, detectable by functional respiratory imaging. Secondary end-points include changes in airway wall thickness, airway resistance and bronchodynamics.

\section{Anti-IL-5/IL-5 receptor}

Mepolizumab is an anti-IL-5 approved as add-on maintenance therapy in patients aged $\geqslant 6$ years with severe eosinophilic asthma [76, 77]. Several studies have investigated the disease-modifying potential of mepolizumab. One study found that mepolizumab treatment of patients with severe asthma led to a reduction in airway mucosal eosinophils and expression of markers of airway remodelling (table 1) [78]. However, following the discontinuation of mepolizumab in the COMET study, patients had a reduced time to first exacerbation, increased frequency of exacerbations, and increased blood eosinophils versus those who continued mepolizumab, implying mepolizumab had not modified the underlying disease [79]. An ongoing study (REMOMEPO; NCT03797404, estimated completion October 2022) is investigating the 
relationship between clinical responses to mepolizumab and airway remodelling changes after 6 and 12 months of treatment: primary outcomes are reticular membrane thickening and ASM area [80].

Benralizumab is an anti-IL-5 receptor treatment that initiates antibody-dependent cell-mediated cytotoxicity, leading to the depletion of eosinophils [81]. Benralizumab is approved as add-on maintenance treatment for patients $\geqslant 12$ years with severe eosinophilic asthma [82]. Using bronchial biopsies and a computational model to simulate airway remodelling seen in severe asthma, results indicated that benralizumab significantly reduced ASM mass (table 1) [83]. An ongoing phase IV study (CHINOOK; NCT03953300, estimated completion September 2023) is investigating the airway remodelling effects of benralizumab in adult patients with severe eosinophilic asthma [84]. Primary outcome measures comprise change in eosinophil numbers in endobronchial biopsies and change in airway wall area by quantitative computed tomography (CT) imaging.

While benralizumab, mepolizumab and omalizumab have publications reporting their effect on lung architecture (e.g. airway wall thickness, ASM proliferation) or effects beyond cessation, there are currently no such reports for reslizumab.

Anti-thymic stromal lymphopoietin (TSLP)

TSLP is a key regulator of asthma pathogenesis. TSLP is an alarmin expressed in the airway epithelium and is released in response to asthma triggers, resulting in a proinflammatory cascade, where TSLP primes dendritic cells to activate T- and B-cells [85].

The treatment of non-T2 inflammation remains a major unmet need in asthma [27], and drugs targeting the non-T2 pathway (anti-IL-17 and anti-tumour necrosis factor $\alpha$ ) have so far been unsuccessful [86]. Anti-TSLP treatments bind to TSLP, preventing the activation of both T2 and non-T2 inflammatory cascades. They act further upstream than other currently approved biologics and could therefore be effective for a broader range of asthma phenotypes. Tezepelumab is an anti-TSLP mAb in development for patients with both eosinophilic and non-eosinophilic severe asthma [87]. The phase III NAVIGATOR trial recently met its primary end-point (reduction in annualised asthma exacerbation rate) [88]. In the phase II PATHWAY trial, tezepelumab decreased markers of inflammation and matrix remodelling (table 1) [89], implying disease-modifying potential. A recent phase II trial (UPSTREAM) found that tezepelumab reduced the proportion of patients with AHR [90]. Another anti-TSLP, CSJ117, is being investigated in patients with asthma. In a 12-week phase I trial, CSJ117 reduced allergen-induced bronchoconstriction in patients with mild asthma [91]. A phase II trial is in progress (NCT04410523) [92].

\section{Limitations of biologics in disease modification}

It is important to note that although some biologics demonstrate disease-modifying potential, there are limitations to their use. Currently, biologics are only available to patients with severe, uncontrolled asthma [22], which is a small percentage of patients with the disease [93]. Additionally, not all patients will respond to these therapies [94], and data on biologics in children and adolescents are limited. In terms of lung function, results with biologics have been varied [70-72, 88, 95], with limited studies to assess their impact on AHR, which may be an intrinsic feature of asthma linked to airway remodelling [20]. As such, further studies are required to assess the disease-modifying potential of biologics.

The high direct cost of biologics currently limits their use to patients who do not respond to ICS/ long-acting $\beta$-agonists [22]; however, if strong evidence for disease modification (and associated long-term clinical benefits) were demonstrated, it is conceivable that payors may view the high cost of biologics as more acceptable.

\section{Small-molecule drugs}

Montelukast is a cysteinyl leukotriene (CysLT) receptor antagonist, approved for the long-term treatment of asthma in adults and children aged $\geqslant 12$ months [96]. CysLTs are released from mucosal mast cells in response to the T2 proinflammatory cascade, contributing to ASM contraction, mucus secretion and airway remodelling (figure 1) [97, 98]. In terms of the disease-modifying potential of montelukast, evidence is mixed. In an allergic asthma murine model, montelukast decreased ASM mass in young developing mice, indicating the potential to reverse (or even prevent) airway remodelling (table 1) [99]; however, in a study in patients with persistent asthma, no significant changes in airway wall area or thickness were found [100].

Another small-molecule drug with potential disease-modifying potential is fevipiprant, an oral prostaglandin $\mathrm{D}_{2}\left(\mathrm{PGD}_{2}\right)$ receptor 2 antagonist previously investigated for the treatment of severe asthma. $\mathrm{PGD}_{2}$ plays a role in mediating eosinophilic inflammation in asthma by stimulating Th2 cells to produce 
IL-4, IL-5 and IL-13 (figure 1) [101]. In a phase III study in patients with moderate asthma, the primary end-point (reduction in annualised rate of exacerbations) was not achieved [102]. However, based on bronchial biopsy data from a phase IIa trial, fevipiprant significantly improved the proportion of intact epithelium and reduced ASM mass after 12 weeks versus placebo, independently of eosinophilic inflammation (table 1) [101, 103]. Furthermore, fevipiprant significantly decreased functional residual capacity and expiratory CT lung volume [101]. A computational model, designed to represent an average patient with asthma and airway remodelling, predicted that a reduction in airway eosinophilia alone was insufficient to explain the clinically observed decrease in ASM mass by fevipiprant; a concomitant reduction in the recruitment of ASM cells (or their precursors) to ASM bundles that comprise the ASM layer must also occur [103]. After treatment completion, all efficacy parameters returned to baseline levels, suggesting that 12 weeks of fevipiprant may not be sufficient to provide a sustained benefit on airway structure [101].

Treatments approved for non-asthma indications

Several therapies indicated for other diseases are now being explored for disease modification properties in asthma (table 1). One example is roflumilast, a phosphodiesterase-4 inhibitor, approved for chronic obstructive pulmonary disease (COPD) [104]. In a murine model of chronic asthma, roflumilast significantly decreased the parameters of airway remodelling [105]. Another example, dasatinib, is a tyrosine kinase inhibitor approved for chronic myeloid leukaemia and acute lymphoblastic leukaemia [106]. In a murine model of asthma, dasatinib attenuated alveolar collapse and contraction index and reduced inflammatory cell influx to the airway, indicating that dasatinib could be used to reduce the remodelling process [107].

Anticalins are small proteins based on human lipocalins, which can be genetically engineered to selectively bind ligand sites, similar to antibodies [108]. The anticalin AZD1402 targets the IL-4R $\alpha$ subunit by a similar mechanism to dupilumab [109]. Results from preclinical studies showed that AZD1402 led to effective in vivo inhibition of eotaxin-3, an eosinophil-specific chemoattractant [109, 110]. AZD1402 is now progressing into clinical trials [111].

\section{Disease modification study considerations}

When designing a trial to investigate disease modification, or interpreting data to evaluate disease modification, several practical aspects should be considered (figure 4).

\section{End-points}

There are many end-points that may be used to assess the disease-modifying effects of asthma therapies. A disease-modifying therapy may have effects on lung structure; therefore, bronchial biopsies, CT and high-resolution CT could be used to assess airway structure, such as airway wall thickness [112, 113]. Biomarkers specific to airway remodelling have been identified and may be utilised as measures of disease modification. Galectin-3 is an IgE-binding protein found to be a reliable biomarker of airway remodelling modulation via reticular basement membrane thickening in severe asthma [114]. In addition, high levels of fibroblast growth factor 2 in sputum have been found to correlate with asthma severity and pulmonary function [115]. Tissue inhibitor of metalloproteinases (TIMP) and matrix metalloproteinase (MMPs) are enzymes involved in ECM composition; the expression of MMP-2 and TIMP-1 in ASM have been correlated with asthma and thus implicated in the airway remodelling process $[116,117]$. However, there is a need for additional biomarkers to assess disease-modifying effects in asthma.

Disease progression in asthma is indicated by an exaggerated loss of lung function over time [15]; therefore, it is valuable to investigate disease measures. Lung function (e.g. forced expiratory volume in one second $\left(\mathrm{FEV}_{1}\right)$ and peak expiratory flow) and exacerbations are the major outcomes used to assess whether progression can be prevented/resolved [16]. Quality of life and asthma control could also be utilised; however, current symptom tests are not fully comprehensive. Corticosteroid use and scheduled and unscheduled healthcare utilisation can also be investigated, as a high medication burden has been associated with exacerbation-prone patients, who are likely to be using a greater number of controller therapies versus those with no or few exacerbations [5].

As asthma is a chronic inflammatory disorder, it may also be valuable to measure markers of airway inflammation, such as sputum and blood eosinophils, $F_{\text {ENO }}$ and IgE (total and antigen-specific) in order to investigate whether they can detect changes earlier than airway remodelling measures. This may be particularly useful when studying patients with T2 asthma (who typically have elevated eosinophils, $F_{\mathrm{ENO}}$ and IgE) and are frequently used as a primary target for currently available biologic treatments [27]. However, other upstream mediators of airway epithelial cells could also be targeted; for example, IL-33 
Disease modification study considerations

$\checkmark$ Choose appropriate end-points

Such as:

- Improvements in measures of disease and symptoms (e.g.

$\mathrm{FEV}_{1}, \mathrm{PEF}$, exacerbations, asthma control, quality of life)

- Reduction in biomarkers specific to airway inflammation

(e.g. sputum/blood eosinophils, $F_{\mathrm{ENO}}, \mathrm{IgE}$ )

- Change in structural airway abnormalities

(e.g. airway wall thickness, ASM area)

- Reduction in biomarkers involved in remodelling

(e.g. galectin-3, FGF2)

$\checkmark$ Choose an appropriate trial length

- Consider trials of $\geq 1$ year

- Consider follow-up studies following drug cessation

$\checkmark$ Be aware of special considerations for paediatric trials

Such as:

- Select noninvasive end-points

- Take into account age-related differences in physiology, pathology and drug metabolism

$\checkmark$ Consider including patients with comorbidities in trials

FIGURE 4 Disease modification study considerations. ASM: airway smooth muscle; FGF2: fibroblast growth factor 2; $F_{\mathrm{ENO}}$ : fractional exhaled nitric oxide; $\mathrm{FEV}_{1}$ : forced expiratory volume in $1 \mathrm{~s}$; IgE: immunoglobulin $\mathrm{E}$; PEF: peak expiratory flow.

has recently been implicated in shaping the immune system of the lungs early in life, at a time which is crucial in the subsequent development of allergic asthma [118]. In cases of non-T2 inflammation, potential biomarkers include sputum neutrophil and IL-17 levels [119], which could be used to investigate the disease-modifying properties of therapies in non-T2 asthma endotypes.

\section{Length of trial}

Although a disease-modifying effect of a treatment could be investigated via incorporation into existing studies as a secondary or exploratory end-point, dedicated studies may also be required. When pre-defining the length of a trial to investigate the disease-modifying efficacy of a treatment, a short-term study will not provide sufficient data; long-term trials of at least a year are needed to elucidate any structural changes or effects on disease progression [120]. Furthermore, follow-up periods after drug cessation are also necessary to determine whether any disease-modifying effects are sustained [120].

\section{Paediatric trials}

When designing a trial to investigate asthma treatments in a paediatric population, it is key to note that there are a number of key age-related differences in physiology, pathology and drug metabolism (as well as in social and emotional factors) between adults and children [120]. Adults with early-onset asthma tend to have a greater loss of lung function than those with adult-onset asthma [33]. Some children will also outgrow their asthma (as we define the disease) spontaneously, although lung function impairment and respiratory symptoms (e.g. cough or phlegm) may still be present years later [121, 122]. Disease progression may be less advanced in children than in adults; therefore, it is likely that for successful disease modification, early intervention could be necessary to achieve optimal results. This has been shown from the use of DMARDs to treat RA; early therapeutic intervention significantly reduces the risk of RA onset [123]. It is also necessary to assess the most effective intervention depending on the stage of asthma development. For example, patients with adult-onset disease tend to respond better to anti-IL-5 or anti-IL-5 receptor biologics [124, 125] and those with early-onset asthma respond better to anti-IgE treatments [22] (where IgE-mediated events are likely to be contributors), though no direct comparator studies for these biologics have been performed. 
Treatment and outcome measures need to be appropriate to the age of the child [120]. In paediatric patients, in whom lung development is ongoing but key, tests that may help to inform diagnosis and management, as well as predict treatment response, are of particular interest. At present, there are a limited number of biomarkers available for paediatric patients (including blood and sputum eosinophils, serum IgE and $F_{\mathrm{ENO}}$ ) and the current gold standard tests for airway inflammation and remodelling (e.g. bronchial biopsies) are invasive and therefore rarely utilised in this population [25]. Therefore, less invasive methods of measuring eosinophilia must be used, making the potential use of lung function outcomes such as FEV 1 as an end-point even more attractive [126]. In addition, the majority of paediatric patients have lung function that is close to normal between symptomatic episodes and, therefore, study design (and patient recruitment) may rely on the documentation of episodes via methods such as questionnaires/diaries completed by caregivers [120]. In some patients for whom spirometry is not feasible (particularly children $<5$ years, but at times in older children/adults), other physiological lung function may be considered. One example is impulse oscillometry, which is a noninvasive forced oscillation method feasible in children as young as 2-3 years that provides information on airway resistance and reactance in both larger and smaller airways [122]. As asthma is often developed in early childhood, trials such as the ongoing omalizumab PARK trial in children 2-3 years of age may be able to determine the disease-modifying effects of omalizumab [67].

\section{Comorbidities}

Comorbidities in patients with asthma are common. In a meta-analysis, patients with asthma had a significantly higher number of comorbidities versus healthy participants; incidences of almost all types of respiratory, cardiovascular, cerebrovascular, metabolic, gastrointestinal, urinary, neurological and psychiatric disorders were higher [127]. Although patients with asthma and comorbidities are often excluded from asthma trials, these conditions could influence the effectiveness and disease-modifying capability of therapies. Several asthma therapies are also utilised for other indications: dupilumab is approved for atopic dermatitis (AD) and nasal polyposis [68, 128]; mepolizumab for hypereosinophilic syndrome [129] and eosinophilic granulomatosis with polyangiitis [76, 130]; and omalizumab for chronic idiopathic urticaria and nasal polyposis [131, 132]. Tezepelumab is currently being investigated for use in patients with $\mathrm{AD}$ [133] and COPD [134]. In order to investigate treatments in patients with asthma comorbidities, it may be desirable to study the effects of any new treatment in a real-world setting, e.g. during late-stage development or effectiveness studies [120].

\section{The future of disease-modifying therapies in asthma}

\section{Genotype-specific risks of asthma}

Asthma is a heritable disorder that is a result of multiple genetic variants, each carrying a small disease risk. Several loci and specific genes are robustly associated with asthma in both children and adults [135] and functional follow-up work of identified genes may reveal biologically plausible candidates and pathways.

The identification of genotype-specific risks of asthma development could lead to an exciting area of development for future disease-modifying drugs. A recent review of genomics-guided discovery of drug targets for asthma identified several plausible candidates, both novel ones and others already approved for non-asthma disorders that could be repurposed (e.g. drugs targeting IL-6) [136]. Risk prediction models using genetic data and insights from recent genome-wide association studies have not proven clinically useful [137, 138], suggesting that novel applications and more targeted models are necessary. Studies on other respiratory traits such as lung function and COPD suggest that polygenic risk scores can identify a small subset of individuals at markedly increased risk for moderate-to-severe disease and patterns of reduced lung growth [139]. It is thought that incorporation of environmental exposures in the risk prediction model may identify susceptible individuals [140, 141], although clinical applications of such gene-environment interaction models are yet to be developed.

Recent research into the well-known chromosome-17 asthma locus found gasdermin B (GSDMB) gene overexpression in the upper epithelial cells of children with asthma [142]. Whether GSDMB (at the RNA or protein level) could be a target for new asthma drugs is a potential area for investigation, with supportive earlier experimental work documented [143]. As loss of epithelial integrity is a key component of the airway remodelling process, being able to treat its underlying cause may be an effective disease-modifying strategy.

One of the key T2 drivers, IL-33, is a top candidate asthma gene identified in large-scale studies [135]. Recently, the IL-33 pathway has been specifically tied to eosinophilic asthma [144]. Therefore, a key area of interest for clinicians is the possibility of a genetic test to identify severe asthma patients with 
IL-33-driven disease in order to guide anti-IL-33 treatment. Clinically, this has not yet been achieved; however, with an unprecedented development of genomic-based tests for precision medicine applications underway, such applications could become available in the near future [145].

\section{Virally induced asthma}

A major risk factor for an asthma diagnosis later in life is the causation of wheezing episodes in children by viral respiratory tract infections; human rhinovirus is one such pathogen associated with asthma exacerbations [146]. One study using human bronchial epithelial cell lines and a murine model of rhinovirus infection demonstrated that rhinovirus has the potential to contribute to remodelling of the airways through induction of ECM deposition [147]. Furthermore, studies in mice have revealed specific genes in the rhinovirus genome that are responsible for increased host IL-13, airway mucus and airway responsiveness, as well as the production of the amino acids responsible for airway remodelling [148]. Certain strains of bacteria can make the airways susceptible to viral infection, whilst others can lead to an enhanced antiviral immune response and reduce the risk of symptomatic viral infection [148]. These findings could subsequently assist in the development of vaccines or therapeutic strategies, such as antibiotics, for the prevention of virally induced asthma. Other viruses, such as respiratory syncytial virus (RSV), have also been implicated in asthma pathogenesis; however, the role of early-life RSV infection in lung growth and development of asthma remains to be defined [149, 150].

\section{The role of the microbiome in asthma}

The environmental microbiome plays a significant role in asthma development; several studies have implicated the role of microbiota in the regulation of immune function and the development of atopy and asthma. One preclinical study using a murine model of allergic airway inflammation found that germ-free mice had elevated levels of eosinophils and lymphocytes compared with control mice, which correlated with increased local production of T2-associated cytokines and elevated IgE production [151]. Furthermore, it is thought that early-life exposure to a diverse microbiota may reduce the risk of asthma development; both early-life and maternal antibiotic use have been associated with increased risk of recurrent wheeze and asthma development in childhood [152, 153]. In addition, the Child, Parent and Health: Lifestyle and Genetic Constitution Birth Cohort Study found that both caesarean section and hospital delivery influenced the gastrointestinal microbiota composition of infants, which subsequently correlated with the later development of atopic manifestations such as asthma [154]. Although specific environmental interventions to increase exposure to microbial diversity are difficult to implement in practice, interventions that help promote a healthy and diverse microbiome (e.g. prebiotics and probiotics) may assist in asthma prevention [155].

\section{Conclusions}

The current mainstay of treatment in asthma is the use of ICS; however, as ICS therapy does not alter the underlying pathophysiology of asthma, further treatment options should be investigated. Following the successful development of disease-modifying treatments in other settings, as well as the current lack of a cure for asthma, the "Holy Grail” of asthma therapy is disease remission or prevention. Novel therapies, such as biologics, have shown the potential to exhibit disease-modifying properties in patients with asthma. However, it is worth noting that this has typically been observed in settings comprising small sample sizes, and biologics are only suitable for a small subset of patients. Larger studies to find disease-modifying treatments that are accessible to more patients are required. In addition, the therapies discussed here have so far only been approved or tested as add-on therapies for patients with asthma. Due to the high treatment burden of multiple therapies, it would be advantageous for new therapies to be effective enough to replace the current therapy, therefore simplifying treatment regimens. From a life-course perspective, the earlier the disease remission or prevention the better, which makes paediatric aspects particularly important. Furthermore, as there is still an unmet need for further studies and improved management, the thorough consideration of several factors relating to asthma pathophysiology and personalised patient care regarding genotype, age and the presence of comorbidities is required.

Provenance: Submitted article, peer reviewed.

Acknowledgements: The authors would like to acknowledge Monica Kraft, University of Arizona College of Medicine, Tucson, AZ, USA, for her input into the concept of this paper as a member of the independent publications Steering Committee. Medical writing support for the development of this manuscript, under the direction of the authors, was provided by Eleanor Thomas, BSc, of Ashfield MedComms, an Ashfield Health company, and funded by Novartis. This publication was written in accordance with Good Publications Practice (GPP3) guidelines (http://www.ismpp.org/gpp3). 
Conflict of interest: W.W. Busse reports consultant fees from AstraZeneca, Genentech, GlaxoSmithKline, Novartis, Regeneron Pharmaceuticals Inc. and Sanofi, outside the submitted work. E. Melén reports advisory board and lecture fees from ALK, Sanofi, Chiesi, Novartis and AstraZeneca, outside the submitted work. E. Melén is supported by grants from the Swedish Research Council, Region Stockholm (ALF), the Swedish Heart-Lung Foundation and ERA PerMed JTC 2018 Call (VR 2018-05619). A.N. Menzies-Gow reports grants and personal fees from AstraZeneca, personal fees from Novartis, attendance at advisory boards from GlaxoSmithKline, attendance at advisory boards and lecture fees from Vectura, personal fees, attendance at advisory boards and non-financial support from Teva, personal fees from Sanofi, personal fees from Vectura, personal fees from GlaxoSmithKline, outside the submitted work.

Support statement: This publication was funded by Novartis Pharma, Basel, Switzerland. Novartis did not have any input in the final content. Funding information for this article has been deposited with the Crossref Funder Registry.

\section{References}

1 GBD Chronic Respiratory Disease Collaborators. Global, regional, and national deaths, prevalence, disability-adjusted life years, and years lived with disability for chronic obstructive pulmonary disease and asthma, 1990-2015: a systematic analysis for the Global Burden of Disease Study 2015. Lancet Respir Med 2017; 5: 691-706

2 Levy BD, Noel PJ, Freemer MM, et al. Future research directions in asthma. An NHLBI working group report. Am J Respir Crit Care Med 2015; 192: 1366-1372.

3 Menzies-Gow A, Bafadhel M, Busse WW, et al. An expert consensus framework for asthma remission as a treatment goal. J Allergy Clin Immunol 2020; 145: 757-765.

4 European Medicines Agency (EMA). Guideline on the clinical investigation of medicines for the treatment of Alzheimer's disease. 2018. www.ema.europa.eu/en/documents/scientific-guideline/guideline-clinicalinvestigation-medicines-treatment-alzheimers-disease-revision-2_en.pdf Date last accessed: September 2020. Denlinger LC, Phillips BR, Ramratnam S, et al. Inflammatory and comorbid features of patients with severe asthma and frequent exacerbations. Am J Respir Crit Care Med 2017; 195: 302-313.

6 Benjamin O, Bansal P, Goyal A, et al. Disease modifying anti-rheumatic drugs (DMARD). In: StatPearls. Treasure Island, Florida, StatPearls Publishing LLC, 2020.

7 Landewé RB, Machado PM, Kroon F, et al. EULAR provisional recommendations for the management of rheumatic and musculoskeletal diseases in the context of SARS-CoV-2. Ann Rheum Dis 2020; 79: 851-858.

8 Jones G, Darian-Smith E, Kwok M, et al. Effect of biologic therapy on radiological progression in rheumatoid arthritis: what does it add to methotrexate? Biologics 2012; 6: 155-161.

9 Taylor PC, Keystone EC, van der Heijde D, et al. Baricitinib versus placebo or adalimumab in rheumatoid arthritis. N Engl J Med 2017; 376: 652-662.

10 Scott IC, Kingsley GH, Scott DL. Can we discontinue synthetic disease-modifying anti-rheumatic drugs in rheumatoid arthritis? Clin Exp Rheumatol 2013; 31: Suppl. 78, S4-S8.

11 Halken S, Larenas-Linnemann D, Roberts G, et al. EAACl guidelines on allergen immunotherapy: Prevention of allergy. Pediatr Allergy Immunol 2017; 28: 728-745.

12 Kim EH, Burks AW. Food allergy immunotherapy: Oral immunotherapy and epicutaneous immunotherapy. Allergy 2020; 75: 1337-1346.

13 Passalacqua G, Rogkakou A, Mincarini M, et al. Allergen immunotherapy in asthma; what is new? Asthma Res Pract 2015; 1: 6.

14 Lemanske RF Jr, Busse WW. Asthma: clinical expression and molecular mechanisms. J Allergy Clin Immunol 2010; 125: S95-S102.

15 McGeachie MJ, Yates KP, Zhou X, et al. Patterns of growth and decline in lung function in persistent childhood asthma. N Engl J Med 2016; 374: 1842-1852.

16 Menzies-Gow A, Szefler SJ, Busse WW. The relationship of asthma biologics to remission for asthma. J Allergy Clin Immunol Pract 2021; 9: 1090-1098.

17 O'Byrne P, Fabbri LM, Pavord ID, et al. Asthma progression and mortality: the role of inhaled corticosteroids. Eur Respir J 2019; 54: 1900491.

18 Robinson D, Humbert M, Buhl R, et al. Revisiting type 2-high and type 2-low airway inflammation in asthma: current knowledge and therapeutic implications. Clin Exp Allergy 2017; 47: 161-175.

19 Chen M, Shepard K II, Yang M, et al. Overlap of allergic, eosinophilic and type 2 inflammatory subtypes in moderate-to-severe asthma. Clin Exp Allergy 2020; 51: 546-555.

20 Bergeron C, Tulic MK, Hamid Q. Airway remodelling in asthma: from benchside to clinical practice. Can Respir J 2010; 17: e85-e93.

21 Fehrenbach H, Wagner C, Wegmann M. Airway remodeling in asthma: what really matters. Cell Tissue Res 2017; 367: 551-569.

22 Global Initiative for Asthma (GINA). 2021 GINA Report, Global Strategy for Asthma Management and Prevention. 2021. https://ginasthma.org/gina-reports/ 
Brusselle G, Bracke K. Targeting immune pathways for therapy in asthma and chronic obstructive pulmonary disease. Ann Am Thorac Soc 2014; 11: Suppl. 5, S322-S328.

Kalinauskaite-Zukauske V, Januskevicius A, Janulaityte I, et al. Expression of eosinophil $\beta$ chain-signaling cytokines receptors, outer-membrane integrins, and type 2 inflammation biomarkers in severe non-allergic eosinophilic asthma. BMC Pulm Med 2019; 19: 158.

Licari A, Castagnoli R, Brambilla I, et al. Asthma endotyping and biomarkers in childhood asthma. Pediatr Allergy Immunol Pulmonol 2018; 31: 44-55.

Jackson DJ, Humbert M, Hirsch I, et al. Ability of serum IgE concentration to predict exacerbation risk and benralizumab efficacy for patients with severe eosinophilic asthma. Adv Ther 2020; 37: 718-729.

Viswanathan RK, Busse WW. How to compare the efficacy of biologic agents in asthma. Ann Allergy Asthma Immunol 2020; 125: 137-149.

Licari A, Manti S, Castagnoli R, et al. Immunomodulation in pediatric asthma. Front Pediatr 2019; 7: 289.

Woodruff PG, Modrek B, Choy DF, et al. T-helper type 2-driven inflammation defines major subphenotypes of asthma. Am J Respir Crit Care Med 2009; 180: 388-395.

Heaney LG, Busby J, Hanratty CE, et al. Composite type-2 biomarker strategy versus a symptom-risk-based algorithm to adjust corticosteroid dose in patients with severe asthma: a multicentre, single-blind, parallel group, randomised controlled trial. Lancet Respir Med 2021; 9: 57-68.

Busby J, Holweg CTJ, Chai A, et al. Change in type-2 biomarkers and related cytokines with prednisolone in uncontrolled severe oral corticosteroid dependent asthmatics: an interventional open-label study. Thorax 2019; 74: 806-809.

Rabe KF, Calhoun WJ, Smith N, et al. Can anti-IgE therapy prevent airway remodeling in allergic asthma? Allergy 2011; 66: 1142-1151.

Tan DJ, Walters EH, Perret JL, et al. Clinical and functional differences between early-onset and late-onset adult asthma: a population-based Tasmanian longitudinal health study. Thorax 2016; 71: 981-987.

Al-Zayadneh EM, Alnawaiseh NA, Altarawneh AH, et al. Sensitization to inhaled allergens in asthmatic children in southern Jordan: a cross-sectional study. Multidiscip Respir Med 2019; 14: 37.

Holgate ST, Lack G. Improving the management of atopic disease. Arch Dis Child 2005; 90: 826-831.

Baldacara RP, Fernandes Mde F, Baldacara L, et al. Prevalence of allergen sensitization, most important allergens and factors associated with atopy in children. Sao Paulo Med J 2013; 131: 301-308.

Murray CS, Woodcock A, Langley SJ, et al. Secondary prevention of asthma by the use of Inhaled Fluticasone propionate in Wheezy INfants (IFWIN): double-blind, randomised, controlled study. Lancet 2006; 368: 754-762.

Guilbert TW, Mauger DT, Allen DB, et al. Growth of preschool children at high risk for asthma 2 years after discontinuation of fluticasone. J Allergy Clin Immunol 2011; 128: 956-963.e951-957.

Devulapalli CS, Lodrup Carlsen KC, Haland G, et al. No evidence that early use of inhaled corticosteroids reduces current asthma at 10 years of age. Respir Med 2007; 101: 1625-1632.

Abrams EM, Szefler SJ, Becker AB. Does inhaled steroid therapy help emerging asthma in early childhood? Lancet Respir Med 2017; 5: 827-834.

Ward C, Pais M, Bish R, et al. Airway inflammation, basement membrane thickening and bronchia hyperresponsiveness in asthma. Thorax 2002; 57: 309-316.

Chetta A, Zanini A, Foresi A, et al. Vascular component of airway remodeling in asthma is reduced by high dose of fluticasone. Am J Respir Crit Care Med 2003; 167: 751-757.

Hoshino M, Ohtawa J, Akitsu K. Effect of treatment with inhaled corticosteroid on serum periostin levels in asthma. Respirology 2015; 21: 297-303.

Hoshino M, Takahashi M, Takai Y, et al. Inhaled corticosteroids decrease vascularity of the bronchial mucosa in patients with asthma. Clin Exp Allergy 2001; 31: 722-730.

Chanez P, Bourdin A, Vachier I, et al. Effects of inhaled corticosteroids on pathology in asthma and chronic obstructive pulmonary disease. Proc Am Thorac Soc 2004; 1: 184-190.

Zahran HS, Bailey CM, Qin X, et al. Long-term control medication use and asthma control status among children and adults with asthma. J Asthma 2017; 54: 1065-1072.

Vähätalo I, Ilmarinen P, Tuomisto LE, et al. Inhaled corticosteroids and asthma control in adult-onset asthma: 12-year follow-up study. Respir Med 2018; 137: 70-76.

Salem IH, Boulet LP, Biardel S, et al. Long-term effects of bronchial thermoplasty on airway smooth muscle and reticular basement membrane thickness in severe asthma. Ann Am Thorac Soc 2016; 13: 1426-1428.

Chakir J, Haj-Salem I, Gras D, et al. Effects of bronchial thermoplasty on airway smooth muscle and collagen deposition in asthma. Ann Am Thorac Soc 2015; 12: 1612-1618.

50 Chaudhuri R, Rubin A, Sumino K, et al. Safety and effectiveness of bronchial thermoplasty after 10 years in patients with persistent asthma (BT10+): a follow-up of three randomised controlled trials. Lancet Respir Med 2021; 9: 457-466.

1 Donovan GM, Elliot JG, Green FHY, et al. Unraveling a clinical paradox: why does bronchial thermoplasty work in asthma? Am J Respir Cell Mol Biol 2018; 59: 355-362. 
d'Hooghe JNS, ten Hacken NHT, Weersink EJM, et al. Emerging understanding of the mechanism of action of bronchial thermoplasty in asthma. Pharmacol Ther 2018; 181: 101-107.

McGregor MC, Krings JG, Nair P, et al. Role of biologics in asthma. Am J Respir Crit Care Med 2019; 199: 433-445.

Pelaia G, Vatrella A, Busceti MT, et al. Cellular mechanisms underlying eosinophilic and neutrophilic airway inflammation in asthma. Mediators Inflamm 2015; 2015: 879783.

Food and Drug Administration (FDA). Highlights of prescribing information. XOLAIR ${ }^{\circledR}$ (omalizumab) for injection, for subcutaneous use. www.accessdata.fda.gov/drugsatfda_docs/label/2016/103976s5225lbl.pdf Date last accessed: 10 September 2020. Date last updated: July 2016.

Kawakami T, Blank U. From IgE to omalizumab. J Immunol 2016; 197: 4187-4192.

Thomson NC, Chaudhuri R. Omalizumab: clinical use for the management of asthma. Clin Med Insights Circ Respir Pulm Med 2012; 6: 27-40.

Casale TB, Luskin AT, Busse W, et al. omalizumab effectiveness by biomarker status in patients with asthma: evidence from PROSPERO, a prospective real-world study. J Allergy Clin Immunol Pract 2019; 7: 156-164.e151. Fong WCG, Azim A, Knight D, et al. Real-world omalizumab and mepolizumab treated difficult asthma phenotypes and their clinical outcomes. Clin Exp Allergy 2021; 51: 1019-1032.

Hanania NA, Fortis S, Haselkorn T, et al. Omalizumab in asthma with fixed airway obstruction: post hoc analysis of EXTRA. J Allergy Clin Immunol Pract 2021; 10: 222-228.

Oliveira MJ, Vieira M, Coutinho D, et al. Severe asthma in obese patients: improvement of lung function after treatment with omalizumab. Pulmonology 2019; 25: 15-20.

Nopp A, Johansson SG, Adédoyin J, et al. After 6 years with Xolair; a 3-year withdrawal follow-up. Allergy 2010; 65: 56-60.

Molimard M, Mala L, Bourdeix I, et al. Observational study in severe asthmatic patients after discontinuation of omalizumab for good asthma control. Respir Med 2014; 108: 571-576.

Hoshino M, Ohtawa J. Effects of adding omalizumab, an anti-immunoglobulin E antibody, on airway wall thickening in asthma. Respiration 2012; 83: 520-528.

Riccio AM, Mauri P, De Ferrari L, et al. Galectin-3: an early predictive biomarker of modulation of airway remodeling in patients with severe asthma treated with omalizumab for 36 months. Clin Transl Allergy 2017; $7: 6$.

Hayashi H, Fukutomi $\mathrm{Y}$, Mitsui $\mathrm{C}$, et al. Omalizumab for aspirin-hypersensitivity and leukotriene overproduction in aspirin-exacerbated respiratory disease: a randomized trial. Am J Respir Crit Care Med 2020; 201: 1488-1498.

ClinicalTrials.gov. NCT02570984: Preventing Asthma in High Risk Kids (PARK). 2015. https://clinicaltrials.gov/ ct2/show/NCT02570984 Date last accessed: September 2020.

Food and Drug Administration (FDA). Highlights of prescribing information. DUPIXENT ${ }^{\oplus}$ (dupilumab) injection, for subcutaneous use. www.accessdata.fda.gov/drugsatfda_docs/label/2018/761055s007lbl.pdf Date last updated: October 2018. Date last accessed: September 2020.

Matsunaga K, Katoh N, Fujieda S, et al. Dupilumab: basic aspects and applications to allergic diseases. Allergol Int 2020; 69: 187-196.

Castro M, Corren J, Pavord ID, et al. Dupilumab efficacy and safety in moderate-to-severe uncontrolled asthma. N Engl J Med 2018; 378: 2486-2496.

Corren J, Castro M, O'Riordan T, et al. Dupilumab efficacy in patients with uncontrolled, moderate-to-severe allergic asthma. J Allergy Clin Immunol Pract 2020; 8: 516-526.

Corren J, Castro M, Ford LB, et al. Dupilumab improves asthma outcomes irrespective of frequency of previous asthma exacerbation history. Ann Allergy Asthma Immunol 2019; 123: 222-224.e221.

Wechsler M, Ford L, Maspero J, et al. P219 Dupilumab is well tolerated and shows sustained efficacy in patients with asthma: LIBERTY asthma traverse. Ann Allergy Asthma Immunol 2020; 125: S33.

Palomares O, Sanchez-Ramon S, Davila I, et al. dlvergEnt: how IgE axis contributes to the continuum of allergic asthma and anti-IgE therapies. Int J Mol Sci 2017; 18: 1328.

ClinicalTrials.gov. NCT04400318: the effect of dupilumab on lung function and related changes in airway volumes detectable by functional respiratory imaging in patients with moderate-severe asthma (VESTIGE). https://clinicaltrials.gov/ct2/show/NCT04400318 Date last updated: January 2022. Date last accessed: October 2021.

Food and Drug Administration (FDA). Highlights of prescribing information. NUCALA ${ }^{\circledast}$ (mepolizumab) for injection, for subcutaneous use. www.accessdata.fda.gov/drugsatfda_docs/label/2015/1255260rig1s000Lbl. pdf Date last updated: November 2015. Date last accessed: July 2020.

GlaxoSmithKline (GSK). Nucala is the first biologic approved in the US for six to 11-year-old children with severe eosinophilic asthma. 12 September 2019. www.gsk.com/en-gb/media/press-releases/nucala-is-the-firstbiologic-approved-in-the-us-for-six-to-11-year-old-children-with-severe-eosinophilic-asthma/ Date last accessed: December 2020. 
Flood-Page P, Menzies-Gow A, Phipps S, et al. Anti-IL-5 treatment reduces deposition of ECM proteins in the bronchial subepithelial basement membrane of mild atopic asthmatics. J Clin Invest 2003; 112: 1029-1036.

Moore WC, Kornmann O, Humbert M, et al. Stopping versus continuing long-term mepolizumab treatment in severe eosinophilic asthma (COMET study). Eur Respir J 2022; 59: 2100396.

ClinicalTrials.gov. NCT03797404: airway remodeling during mepolizumab treatment (REMOMEPO). www. clinicaltrials.gov/ct2/show/NCT03797404 Date last updated: 20 May 2020. Date last accessed: 7 January 2021.

Bagnasco D, Caminati M, Ferrando M, et al. Anti-IL-5 and IL-5Ra: efficacy and safety of new therapeutic strategies in severe uncontrolled asthma. Biomed Res Int 2018; 2018: 5698212.

Food and Drug Administration (FDA). Highlights of prescribing information. FASENRA ${ }^{\mathrm{TM}}$ (benralizumab) injection, for subcutaneous use. www.accessdata.fda.gov/drugsatfda_docs/label/2017/761070s000lbl.pdf Date last accessed: 24 July 2020.

Chachi L, Diver S, Kaul H, et al. Computational modelling prediction and clinical validation of impact of benralizumab on airway smooth muscle mass in asthma. Eur Respir J 2019; 54: 1900930.

ClinicalTrials.gov. NCT03953300: benralizumab airway remodeling study in severe eosinophilic asthmatics (CHINOOK). www.clinicaltrials.gov/ct2/show/NCT03953300 Date last updated: 2 December 2020. Date last accessed: 7 January 2021.

Kuruvilla ME, Lee FE, Lee GB. Understanding asthma phenotypes, endotypes, and mechanisms of disease Clin Rev Allergy Immunol 2019; 56: 219-233.

Thomson NC. Novel approaches to the management of noneosinophilic asthma. Ther Adv Respir Dis 2016; 10: 211-234.

Corren J, Parnes JR, Wang L, et al. Tezepelumab in adults with uncontrolled asthma. N Engl J Med 2017; 377: 936-946.

Menzies-Gow A, Corren J, Bourdin A, et al. Tezepelumab in adults and adolescents with severe, uncontrolled asthma. N Engl J Med 2021; 384: 1800-1809.

Sridhar S, Zhao W, Pham T-H, et al. Tezepelumab decreases matrix remodelling and inflammatory pathways in patients with asthma. Eur Respir J 2019; 54: Suppl. 63, RCT3785.

Sverrild A, Hansen S, Hvidtfeldt M, et al. The effect of ezepelumab on airway hyperresponsiveness to mannitol in asthma (UPSTREAM). Eur Respir J 2021; 59: 2101296.

Gauvreau GM, Hohlfeld JM, Grant S, et al. Efficacy and safety of an inhaled anti-TSLP antibody fragment in adults with mild atopic asthma. Am J Respir Crit Care Med 2020; 201: A4207.

ClinicalTrials.gov. NCT04410523. Study of efficacy and safety of CSJ117 in patients with severe uncontrolled asthma. www.clinicaltrials.gov/ct2/show/NCT04410523 Date last updated: 9 March 2021. Date last accessed: 11 March 2021.

Dharmage SC, Perret JL, Custovic A. Epidemiology of asthma in children and adults. Front Pediatr 2019; 7: 246. Mukherjee M, Forero DF, Tran S, et al. Suboptimal treatment response to anti-IL-5 monoclonal antibodies in severe eosinophilic asthmatics with airway autoimmune phenomena. Eur Respir J 2020; 56: 2000117.

Eger K, Kroes JA, ten Brinke A, et al. Long-term therapy response to anti-IL-5 biologics in severe asthma-a real-life evaluation. J Allergy Clin Immunol Pract 2021; 9: 1194-1200.

Food and Drug Administration (FDA). Highlights of prescribing information. SINGULAIR ${ }^{\circledR}$ (montelukast sodium) tablets, for oral use. SINGULAIR ${ }^{\circledR}$ (montelukast sodium) chewable tablets, for oral use. SINGULAIR ${ }^{\circledR}$ (montelukast sodium) oral granules. www.accessdata.fda.gov/drugsatfda_docs/label/2020/020829s073, 020830s075,021409s051lbl.pdf Date last accessed: September 2020. Date last updated: April 2020.

Bradding P, Walls AF, Holgate ST. The role of the mast cell in the pathophysiology of asthma. J Allergy Clin Immunol 2006; 117: 1277-1284.

Ikram A, Kumar V, Taimur M, et al. Role of montelukast in improving quality of life in patients with persistent asthma. Cureus 2019; 11: e5046.

Debelleix S, Siao-Him Fa V, Begueret $\mathrm{H}$, et al. Montelukast reverses airway remodeling in actively sensitized young mice. Pediatr Pulmonol 2018; 53: 701-709.

Hoshino M, Ohtawa J, Akitsu K, et al. Effect of the addition of montelukast on airway inflammation and remodeling in symptomatic asthma. Eur Respir J 2017; 50: Suppl. 61, PA4680.

1 Gonem S, Berair R, Singapuri A, et al. Fevipiprant, a prostaglandin D2 receptor 2 antagonist, in patients with persistent eosinophilic asthma: a single-centre, randomised, double-blind, parallel-group, placebocontrolled trial. Lancet Respir Med 2016; 4: 699-707.

Brightling CE, Gaga M, Inoue H, et al. Effectiveness of fevipiprant in reducing exacerbations in patients with severe asthma (LUSTER-1 and LUSTER-2): two phase 3 randomised controlled trials. Lancet Respir Med 2021; 9: 43-56.

03 Saunders R, Kaul H, Berair R, et al. DP2 antagonism reduces airway smooth muscle mass in asthma by decreasing eosinophilia and myofibroblast recruitment. Sci Transl Med 2019; 11: eaao6451.

Food and Drug Administration (FDA). Highlights of prescribing information. DALIRESP® (roflumilast) tablets. www.accessdata.fda.gov/drugsatfda_docs/label/2013/022522s003lbl.pdf Date last accessed: September 2020. Date last updated: August 2013. 
105 Kim SW, Kim JH, Park CK, et al. Effect of roflumilast on airway remodelling in a murine model of chronic asthma. Clin Exp Allergy 2016; 46: 754-763.

106 Food and Drug Administration (FDA). Highlights of prescribing information. SPRYCEL ${ }^{\circledR}$ (dasatinib) tablet for oral use. www.accessdata.fda.gov/drugsatfda_docs/label/2010/021986s7s8lbl.pdf Date last accessed: September 2020. Date last updated: October 2010.

107 da Silva AL, Magalhaes RF, Branco VC, et al. The tyrosine kinase inhibitor dasatinib reduces lung inflammation and remodelling in experimental allergic asthma. Br J Pharmacol 2016; 173: 1236-1247.

108 Simeon R, Chen Z. In vitro-engineered non-antibody protein therapeutics. Protein Cell 2018; 9: 3-14.

109 Pardali K, Jiang F, Fitzgerald M, et al. AZD1402/PRS-060, an inhaled Anticalin ${ }^{\circledR}$ IL-4Ra antagonist, potently inhibits IL-4 induced functional effects in human whole blood, which can be employed translationally in clinical studies. Eur Respir J 2018; 52: Suppl. 62, PA5248.

110 Matschiner G, Allersdorfer A, Rattenstetter B, et al. Discovery and development of AZD1402/PRS-060 a potent and selective blocker of the IL-4 receptor alpha. Am J Respir Crit Care Med 2018; 197: A1354.

111 ClinicalTrials.gov. NCT04643158: efficacy and safety of three inhaled dose levels of AZD1402 administered for four weeks in adults with asthma on medium dose inhaled corticosteroids. https://clinicaltrials.gov/ct2/ show/NCT04643158 Date last updated: January 2022. Date last accessed: December 2020.

112 Walker C, Gupta S, Hartley R, et al. Computed tomography scans in severe asthma: utility and clinical implications. Curr Opin Pulm Med 2012; 18: 42-47.

113 Benayoun L, Druilhe A, Dombret MC, et al. Airway structural alterations selectively associated with severe asthma. Am J Respir Crit Care Med 2003; 167: 1360-1368.

114 Mauri P, Riccio AM, Rossi R, et al. Proteomics of bronchial biopsies: galectin-3 as a predictive biomarker of airway remodelling modulation in omalizumab-treated severe asthma patients. Immunol Lett 2014; 162: 2-10.

115 Bissonnette EY, Madore AM, Chakir J, et al. Fibroblast growth factor-2 is a sputum remodeling biomarker of severe asthma. J Asthma 2014; 51: 119-126.

116 Sivakoti K, Chaya SK, Jayaraj BS, et al. Evaluation of inflammatory markers MMP-2 and TIMP-1 in asthma. Eur Respir J 2018; 52: Suppl. 62, PA5044.

117 Elshaw SR, Henderson N, Knox AJ, et al. Matrix metalloproteinase expression and activity in human airway smooth muscle cells. Br J Pharmacol 2004; 142: 1318-1324.

118 Johansson K, McSorley HJ. Interleukin-33 in the developing lung-roles in asthma and infection. Pediatr Allergy Immunol 2019; 30: 503-510.

119 Wan XC, Woodruff PG. Biomarkers in severe asthma. Immunol Allergy Clin North Am 2016; 36: 547-557.

120 Holgate ST, Bousquet J, Chung KF, et al. Summary of recommendations for the design of clinical trials and the registration of drugs used in the treatment of asthma. Respir Med 2004; 98: 479-487.

121 Omori K, Iwamoto $\mathrm{H}$, Yamane $\mathrm{T}$, et al. Clinically remitted childhood asthma is associated with airflow obstruction in middle-aged adults. Respirology 2017; 22: 86-92.

122 Melén E, Guerra S, Hallberg J, et al. Linking COPD epidemiology with pediatric asthma care: Implications for the patient and the physician. Pediatr Allergy Immunol 2019; 30: 589-597.

123 Hilliquin S, Hugues B, Mitrovic S, et al. Ability of disease-modifying antirheumatic drugs to prevent or delay rheumatoid arthritis onset: a systematic literature review and meta-analysis. Ann Rheum Dis 2018; 77: 1099-1106.

124 Bleecker ER, Wechsler ME, FitzGerald JM, et al. Baseline patient factors impact on the clinical efficacy of benralizumab for severe asthma. Eur Respir J 2018; 52: 1800936.

125 Brusselle G, Germinaro M, Weiss S, et al. Reslizumab in patients with inadequately controlled late-onset asthma and elevated blood eosinophils. Pulm Pharmacol Ther 2017; 43: 39-45.

126 Bush A. Pathophysiological mechanisms of asthma. Front Pediatr 2019; 7: 68.

127 Su X, Ren Y, Li M, et al. Prevalence of comorbidities in asthma and nonasthma patients: a meta-analysis. Medicine 2016; 95: e3459.

128 Food and Drug Administration (FDA). FDA approves first treatment for chronic rhinosinusitis with nasal polyps. www.fda.gov/news-events/press-announcements/fda-approves-first-treatment-chronic-rhinosinusitisnasal-polyps Date last updated: 26 June 2019.

129 Food and Drug Administration (FDA). FDA approves first drug to treat group of rare blood disorders in nearly 14 years. www.fda.gov/news-events/press-announcements/fda-approves-first-drug-treat-group-rareblood-disorders-nearly-14-years Date last updated: 25 September 2020.

130 GlaxoSmithKline (GSK). GSK achieves approval for Nucala (mepolizumab) for the treatment of eosinophilic granulomatosis with polyangiitis (EGPA) for adults in the US. www.gsk.com/en-gb/media/press-releases/gskachieves-approval-for-nucala-mepolizumab-for-the-treatment-of-eosinophilic-granulomatosis-with-polyangiitisegpa-for-adults-in-the-us/ Date last updated: 12 December 2017.

131 Food and Drug Administration (FDA). Highlights of prescribing information. XOLAIR (omalizumab) injection, for subcutaneous use. www.accessdata.fda.gov/drugsatfda_docs/label/2021/103976s5238lbl.pdf Date last updated: 4 September 2021. Date last accessed: October 2021. 
132 Gevaert P, Omachi TA, Corren J, et al. Efficacy and safety of omalizumab in nasal polyposis: 2 randomized phase 3 trials. J Allergy Clin Immunol 2020; 146: 595-605.

133 ClinicalTrials.gov. NCT03809663. A dose ranging placebo-controlled double-blind study to evaluate the safety and efficacy of tezepelumab in atopic dermatitis. https://clinicaltrials.gov/ct2/show/NCT03809663 Date last accessed: December 2020.

134 ClinicalTrials.gov. NCT04039113. Tezepelumab COPD exacerbation study (COURSE). https://clinicaltrials.gov/ ct2/show/NCT04039113 Date last accessed: December 2020.

135 Demenais F, Margaritte-Jeannin P, Barnes KC, et al. Multiancestry association study identifies new asthma risk loci that colocalize with immune-cell enhancer marks. Nat Genet 2018; 50: 42-53.

136 El-Husseini ZW, Gosens R, Dekker F, et al. The genetics of asthma and the promise of genomics-guided drug target discovery. Lancet Respir Med 2020; 8: 1045-1056.

137 Belsky DW, Sears MR, Hancox RJ, et al. Polygenic risk and the development and course of asthma: an analysis of data from a four-decade longitudinal study. Lancet Respir Med 2013; 1: 453-461.

138 Dijk FN, Folkersma C, Gruzieva O, et al. Genetic risk scores do not improve asthma prediction in childhood. J Allergy Clin Immunol 2019; 144: 857-860.e857.

139 Moll M, Sakornsakolpat P, Shrine N, et al. Chronic obstructive pulmonary disease and related phenotypes: polygenic risk scores in population-based and case-control cohorts. Lancet Respir Med 2020; 8: 696-708.

140 Hüls A, Vanker A, Gray D, et al. Genetic susceptibility to asthma increases the vulnerability to indoor air pollution. Eur Respir J 2020; 55: 1901831.

141 Gref A, Merid SK, Gruzieva O, et al. Genome-wide interaction analysis of air pollution exposure and childhood asthma with functional follow-up. Am J Respir Crit Care Med 2017; 195: 1373-1383.

142 Ober C, McKennan CG, Magnaye KM, et al. Expression quantitative trait locus fine mapping of the 17q12-21 asthma locus in African American children: a genetic association and gene expression study. Lancet Respir Med 2020; 8: 482-492.

143 Melén E. Asthma genetics revisited: understanding disease mechanisms by studying ethnically diverse groups. Lancet Respir Med 2020; 8: 427-429.

144 Ketelaar ME, Portelli MA, Dijk FN, et al. Phenotypic and functional translation of IL33 genetics in asthma. J Allergy Clin Immunol 2021; 147: 144-157.

145 Schork AJ, Schork MA, Schork NJ. Genetic risks and clinical rewards. Nat Genet 2018; 50: 1210-1211.

146 Busse WW, Lemanske RF Jr, Gern JE. Role of viral respiratory infections in asthma and asthma exacerbations. Lancet 2010; 376: 826-834.

147 Kuo C, Lim S, King NJ, et al. Rhinovirus infection induces expression of airway remodelling factors in vitro and in vivo. Respirology 2011; 16: 367-377.

148 Altman MC, Beigelman A, Ciaccio C, et al. Evolving concepts in how viruses impact asthma: a work group report of the Microbes in Allergy Committee of the American Academy of Allergy, Asthma \& Immunology. J Allergy Clin Immunol 2020; 145: 1332-1344.

149 Shi T, Ooi Y, Zaw EM, et al. association between respiratory syncytial virus-associated acute lower respiratory infection in early life and recurrent wheeze and asthma in later childhood. J Infect Dis 2020; 222: S628-s633.

150 Simões EAF, Liu AH. RSV prevention in infancy and asthma in later life. Lancet Respir Med 2018; 6: e30.

151 Herbst T, Sichelstiel A, Schar C, et al. Dysregulation of allergic airway inflammation in the absence of microbial colonization. Am J Respir Crit Care Med 2011; 184: 198-205.

152 Loverdos K, Bellos G, Kokolatou L, et al. Lung microbiome in asthma: current perspectives. J Clin Med 2019; 8: 1967.

153 Stensballe LG, Simonsen J, Jensen SM, et al. Use of antibiotics during pregnancy increases the risk of asthma in early childhood. J Pediatr 2013; 162: 832-838.e833.

154 van Nimwegen FA, Penders J, Stobberingh EE, et al. Mode and place of delivery, gastrointestinal microbiota, and their influence on asthma and atopy. J Allergy Clin Immunol 2011; 128: 948-955.

155 Huang YJ. Asthma microbiome studies and the potential for new therapeutic strategies. Curr Allergy Asthma Rep 2013; 13: 453-461.

156 Corren J, Kavati A, Ortiz B, et al. Efficacy and safety of omalizumab in children and adolescents with moderate-to-severe asthma: a systematic literature review. Allergy Asthma Proc 2017; 38: 250-263. 